\title{
Article \\ Building Stock Energy Model: Towards a Stochastic Approach
}

\author{
Marta J. N. Oliveira Panão ${ }^{1, *(1)}$ and André Penas ${ }^{2}$ \\ 1 Instituto Dom Luiz (IDL), Faculdade de Ciências da Universidade de Lisboa, Campo Grande, \\ 1749-016 Lisboa, Portugal \\ 2 Becquerel Institute, 1000 Brussels, Belgium; a.penas@becquerelinstitute.eu \\ * Correspondence: mopanao@fc.ul.pt
}

Citation: Oliveira Panão, M.J.N.; Penas, A. Building Stock Energy

Model: Towards a Stochastic

Approach. Energies 2022, 15, 1420.

https://doi.org/10.3390/en15041420

Academic Editors: Nuno Simões,

Catarina Serra and Tapas Mallick

Received: 26 January 2022

Accepted: 11 February 2022

Published: 15 February 2022

Publisher's Note: MDPI stays neutral with regard to jurisdictional claims in published maps and institutional affiliations.

Copyright: () 2022 by the authors. Licensee MDPI, Basel, Switzerland. This article is an open access article distributed under the terms and conditions of the Creative Commons Attribution (CC BY) license (https:// creativecommons.org/licenses/by/ $4.0 /)$.

\begin{abstract}
This work uses the outcome of a computational tool that performs Energy Performance Certification (EPC) data processing and transforms raw data into comparable data. Multi-correlation among variables results in probability distributions for the most relevant form and fabric building parameters. The model consistently predicts the distributions for heating and cooling energy needs for the Lisbon Metropolitan Area, with an error below 7\% for the first, second and third quartiles. Differences in the energy needs estimation are below $6 \%$ when comparing the seasonal steady-state with the resistance-capacitance ( $R C$ ) model, which proved to be a robust alternative algorithm capable of modeling hourly user profiles. The RC model calculates electricity consumption for actual, adequate, and minimum thermal comfort scenarios corresponding to different user profiles. The actual scenario, built from statistics and a previous survey, defines a reference to evaluate other scenarios for the mean electricity consumption for space heating and cooling in the building units with those systems. The results show that the actual mean electricity consumption for heating $(610 \mathrm{kWh} / \mathrm{y})$ is slightly above the minimum $(512 \mathrm{kWh} / \mathrm{y})$, with $37 \%$ of building units potentially under heated. The electricity consumption $(108 \mathrm{kWh} / \mathrm{y})$ for cooling is below the minimum $(129 \mathrm{kWh} / \mathrm{y})$.
\end{abstract}

Keywords: building stock energy model; probability distribution; electricity consumption; heating; cooling; residential

\section{Introduction}

Predicting the heating and cooling energy consumption of the building stock is critical to delineate the required renovation strategies according to the Renovation Wave for Europe program [1]. The same applies to understanding the paradox of excess mortality in mild winter climates and its relation to energy poverty [2,3] or accounting for the building sector's share for regional and national energy and climate plans (NECP) [4]. It is not less important to understand how buildings perform to more extensive heat waves, and the corresponding impact on summer mortality [5]. Therefore, there is an urgent need to promote operational tools to support energy policies and answer specific energy use questions in the residential building stock.

The building stock energy modeling (BSEM), also known as urban building energy modeling (UBEM), was in 2016 a nascent field [6] but has extensively increased during the last years [7]. A recent review [8] cited almost 300 references, describing numerous models and techniques with the common goal of predicting building stock energy consumption, covering a spatial scale from a city block to an entire city.

The remarkable development of this research area required a revision of the previous classification [9]. Therefore, Langevin et al. [10] updated it, using a multi-layer quadrant scheme where top-down and bottom-up define the horizontal axis's energy model design. The degree of transparency (vertical axis) distinguishes white-box (meaning physics-based) from black-box approaches. Models from all quadrants aim to address one or more of the following issues: forecasting and prediction, profiling, mapping or benchmarking. The determinant factors for the energy prediction corresponding to different layers are 
environmental context, building stock itself and occupants' energy-related behaviors [10]. In their review, Hong et al. [7] identified two main areas requiring further developments: modeling occupant behavior and end-use disaggregation for black-box models.

Energy Performance Certificates (EPC) provide important building-stock-related information not considered in the census but EPC data have flaws. For example, Ahern and Norton [11] concluded that models overestimate primary energy up to $70 \%$ by using default values for unknown parameters. In addition, Dall'O et al. [12] found $24 \%$ EPC with unreliable information. Notwithstanding, EPC constitutes the large primary source of updated building stock data. Except for a few countries with an operational rating EPC system, such as Sweden [13], the EPC rating uses calculated energy consumption, which may significantly differ from operational energy [14]. This negative performance gap is higher in pre-retrofitted buildings when compared to those retrofitted [15]. The uncertainty associated with determinant factors from the three layers certainly explains performance gaps.

Furthermore, the simplified approaches developed for Northern and Central European countries where heating is dominant, usually steady-state methods, are far from appropriate for Mediterranean countries [16], where cooling is not negligible and intermittent heating is the standard practice. Vivian et al. [17] compared the performance of two lumped capacitance models, a first-order (5R1C) and a second-order (7R2C), with advanced energy simulation tools (TRNSYS), considering intermittent heating and cooling in different climate conditions. They concluded that the second-order model improves the peak loads and energy consumption prediction compared to the first-order. Because of the resistancecapacitance's (RC) low complexity, both in inputs and computation load, they would have a prominent role in the future of white-box bottom-up approaches [18].

Changing the object scale from the building to the urban scale requires a detailed evaluation of the complexity modeling level. Focusing the energy calculations on a few building archetypes significantly decreases the computation load [19]. However, identifying the representative buildings using pre-defined criteria such as typology and construction period requires expert intervention and reduces the building stock heterogeneity. Goy et al. [20] explored semi-supervised or unsupervised building clustering techniques to obtain representative buildings. They showed that those are strictly related to the final indices (in their study, heating demand), supporting that representative buildings are only valid for specified indices. Assuming that descriptive parameters are distributions instead of fixed values is an alternative approach to archetypes because it preserves the building stock diversity [21]. By defining them as probability distributions, the unknown or uncertain archetypes parameters result in a combined solution to the lack of variety of archetypes [22]. Moreover, Ben and Steemers [23] explored the extension of building archetypes to households to overcome the significant variations found in occupant behavior. Findings from statistical analyses of behavioral patterns resulted in five household archetypes: active spenders, conscious occupiers, average users, conservers and inactive users [24].

We have learned so far that adapting previous energy models is not a straightforward solution because those were developed for a particular context, taking into account the local climate, socio-economic and cultural aspects and building architecture. Due to the interdisciplinary topic, predicting heating and cooling energy consumption at a large scale is far from a deterministic science. Furthermore, energy models should consider the variability that comes from the cultural context and socio-economic conditions.

The remarkable low heating and cooling energy consumption of some Southern European countries emphasizes the critical research challenge. For example, in Portugal, achieving thermal comfort is still a non-priority expense even for large-income households [25]. Space heating and cooling are often perceived as no basic needs. In fact, during interviews, Horta et al. [26] found those who consider that feeling cold (or hot) at home in winter (or summer) is acceptable.

Specifically for Portugal, some studies used EPC data for the residential building stock characterization. Magalhães and Leal [27] used EPC energy demand to quantify the 
heating performance gap. Palma et al. [28] used 176 different typologies to calculate the energy performance gap by comparing the theoretical with actual energy consumption. Silva et al. [29] estimated the energy use for mobility, space heating and space cooling for Porto city using neural networks to study different urban configurations.

These studies consider seasonal steady-state energy demand, calculated using raw data from buildings or EPC indicators. A significant step to support future BSEM consisted of collecting, mapping, cleansing and integrating urban building data, resulting in 18 archetypes of the residential building stock for a case-study of the Lisbon area [30]. Moreover, space heating and cooling energy demand obtained by building simulation for 10 building typologies were inputs for the Évora city energy model [31].

On the other hand, Fonseca and Panão [32] applied the Monte Carlo method to model the residential building stock and calculate the energy performance indicators using input data as probability distributions. Afterward, Panão and Brito [33] applied that building stock characterization for profiling the electricity use in Lisbon city, adding stochastic modeling of user behavior, which accurately predicted hourly profiling electricity use in Lisbon dwellings. Figueiredo et al. [34] extended the hourly energy calculation to predict electricity loads in future climates.

The identified barriers that this research intends to tackle are: (1) heating and cooling steady-state energy models (based on degree-days) are not accurate predictive models of intermittent heating and cooling; (2) archetypes or representative buildings narrow the variability found in the building stock; (3) energy performance certificates collect data but are useless in characterizing user profiles. This research is a step forward in the previously developed models [32-34] since it intends to explore other statistical techniques of generating the building stock model and shift to transient energy calculations using RC modeling. Strengths and weaknesses of previous models developed by the authors are summarized in Table 1.

Table 1. Strengths and weaknesses of previous models.

\begin{tabular}{|c|c|c|c|}
\hline Model & Spatial Resolution & Strengths & Weaknesses \\
\hline $\begin{array}{c}\text { Fonseca and } \\
\text { Panão [32] }\end{array}$ & Portugal & $\begin{array}{l}\text { Building stock } \\
\text { variability }\end{array}$ & $\begin{array}{c}\text { No statistical } \\
\text { correlation among } \\
\text { parameters; } \\
\text { Seasonal steady-state } \\
\text { energy balance; } \\
\text { EPC energy needs as } \\
\text { the outcome }\end{array}$ \\
\hline Panão and Brito [33] & Lisbon & $\begin{array}{l}\text { Building stock and } \\
\text { user profile } \\
\text { variability; }\end{array}$ & $\begin{array}{c}\text { No statistical } \\
\text { correlation among } \\
\text { parameters; }\end{array}$ \\
\hline \multirow[t]{2}{*}{ Figueiredo et al. [34] } & Portugal & Hourly calculations; & $\begin{array}{c}\text { Steady-state energy } \\
\text { balance }\end{array}$ \\
\hline & & $\begin{array}{c}\text { Electricity } \\
\text { consumption as the } \\
\text { outcome }\end{array}$ & \\
\hline
\end{tabular}

The paper is organized as follows. Section 2 describes the statistical techniques to generate the building stock, the energy modeling approaches, the case-study area and other modeling assumptions. The results and discussion section (Section 3) includes a first validation by comparing EPC data with the calculated energy needs. Furthermore, it compares steady-state energy needs with those calculated by an RC model. Finally, it presents a sensitive study of how user profiles influence energy needs and electricity consumption for heating and cooling. The paper closes with the conclusion section (Section 4). 


\section{Materials and Methods}

The methodology flow diagram (Figure 1) summarizes the study methods and purposes. Section 2.1 describes the statistical methods that generate the building stock, namely, the building form-steps (1), (2), and (3)-and fabric (4). The method is applied to the case-study area presented in Section 2.2. The energy needs calculated by EPC are used to validate the building stock generation, which constitutes the first study purpose. Afterward, statistical methods are applied in the generation of hourly user profiles for nominal, actual, adequate and minimum conditions described in Section 2.3. The second purpose is to compare the energy calculations using two different approaches: seasonal steady-state and hourly RC (Section 2.4). Hourly profiles are required to test the use of the RC model to compute the electricity consumption for space heating and cooling. The electricity consumption is compared with average data from statistics (third purpose) for actual conditions. Finally, to illustrate the model applicability and potential (fourth purpose), the calculated electricity consumption for adequate and minimum conditions is compared with the calculated electricity for actual consumption to infer the number of buildings without thermal comfort (under-heated in Winter or overheated in Summer). Climate data used for the case-study area are presented in Section 2.5.
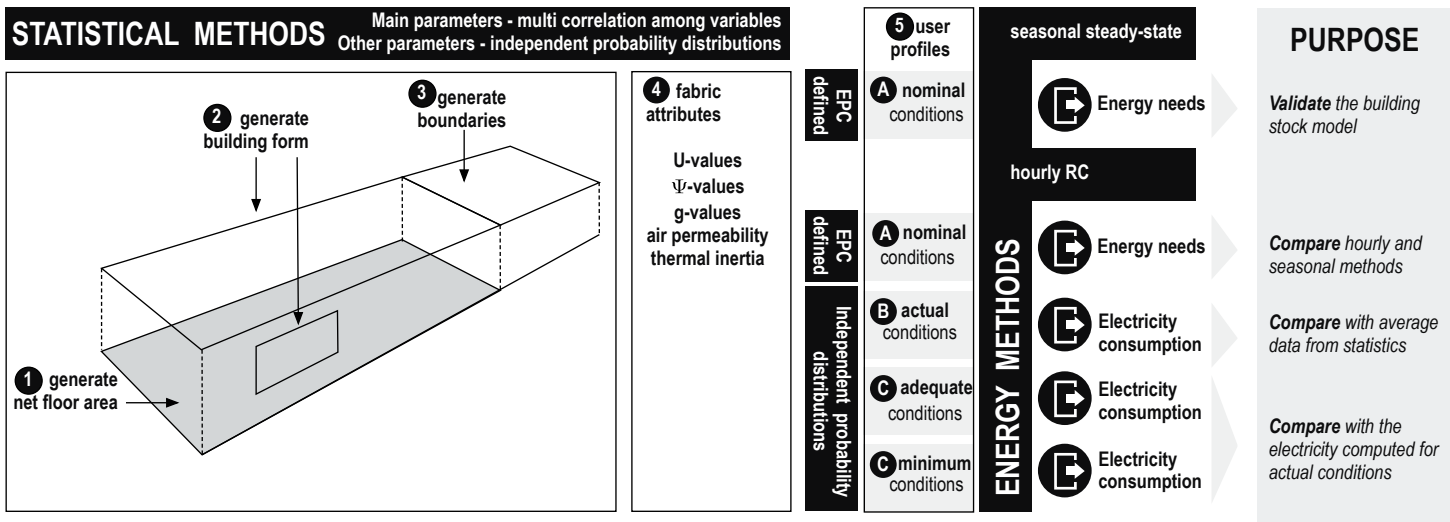

Figure 1. Methodology flow diagram.

\subsection{Building-Stock Generation}

The computational tool developed in [35] uses raw data from energy performance certificates of residential building units in Portugal, issued during 2008 to 2018. It performs data processing and analysis of the main parameters related to form (e.g., net floor area, walls, roof, ground floor and window areas) and fabric (e.g., envelope U-values, glazing and shading devices g-value and air permeability). Raw data are transformed into comparable data, using normalization (e.g., window-to-floor area, opaque-to-floor area) or weighted average values (e.g., mean window U-value and g-value). Evaluations can be performed by context (new, existing, or major renovation), by NUTS III (corresponding to the third territorial statistical subdivision of the Portuguese National Statistics) or by the mix of the two. Probability distributions are the main output of the computational tool obtained by searching for the best fitting considering the likelihood criteria.

Modeling building stock requires a dataset of building parameters capable of recreating a theoretical sample of building units. The method tested here consists of applying the Gaussian copula method [21,36]. The evaluation uses multi-correlation among seven main parameters: opaque-to-floor area, window-to-floor area, window, external wall and roof Uvalues, glazing and shading g-values (Table 2). The remaining are stochastically generated based on independent probability distributions because no strong correlation is expected. 
Table 2. Generation method of building form and fabric parameters.

\begin{tabular}{|c|c|c|}
\hline Generation Method & Building Form & Building Fabric \\
\hline Independent probability distribution & $\begin{array}{c}\text { Net floor area }{ }^{1} \\
\text { Windows orientation } \\
\text { Thermal bridge length-to-opaque area } \\
\text { Internal }^{3} \text { envelope-to-opaque area } \\
\text { Ceiling-to-floor length }\end{array}$ & $\begin{array}{l}\text { Internal }^{3} \text { envelope U-value } \\
\text { Linear thermal bridge } \psi \text {-value } \\
\text { Thermal inertia class } \\
\text { Mean air infiltration }\end{array}$ \\
\hline $\begin{array}{l}\text { Multi-correlation using } \\
\text { Gaussian copula method }\end{array}$ & $\begin{array}{l}\text { Opaque-to-floor area }{ }^{2} \\
\text { Window-to-floor area }\end{array}$ & $\begin{array}{l}\text { Mean windows U-value } \\
\text { Mean external walls U-value } \\
\text { Mean external roofs U-value } \\
\text { Mean glazing g-value } \\
\text { Mean shading g-value }\end{array}$ \\
\hline
\end{tabular}

${ }^{1}$ Primary parameter used to generate opaque and window areas. ${ }^{2}$ Secondary parameter used to generate thermal bridge length and internal envelope area. ${ }^{3}$ Envelope separating the net volume from unheated spaces.

The Gaussian copula method uses a training dataset-the EPC processed data-to compute the covariance matrix used in the sample generation. The training data are form and fabric parameters from the computational tool split into (i) building units with an external roof (e.g., detached, semi-detached houses, last floor apartments) and (ii) without an external roof (e.g., middle floor apartments). For each parameter, the original vector $x_{k}$ is transformed into a vector $\tau_{k}$ formed by the corresponding percentiles obtained to each position $k$. Afterward, the distribution of values within the interval $[0,1]$ is converted into a normal distribution with a mean and standard deviation equal to 0 and 1 , respectively, by applying the following transformation:

$$
\chi \rightarrow \sqrt{2} \operatorname{erf}^{-1}(2 \chi-1)
$$

The covariance matrix results directly from the matrix composed of the transformed vectors, and it is used in the random generation of normal distributions for the seven parameters. The theoretical sample is obtained by reversing the initial transformation.

The primary parameter used to rebuild geometry is the net floor area. The generation of windows and opaque envelope areas comes directly from the net floor area, windowto-floor area and opaque-to-floor area. The secondary parameter is the opaque envelope area, used to determine the thermal bridge length and the envelope area separating the net volume from unheated spaces. Selecting primary and secondary parameters prevents the generation of unrealistic geometries. The overall descriptive parameters required to calculate energy needs are obtained after generating the geometry of a sample of $N$ theoretical building units. Examples of those are opaque envelope heat conductance $\left(H_{o p}\right)$ and window heat conductance $\left(H_{w}\right)$, directly resulting from multiplying envelope U-values and areas. The same applies to effective solar collection areas $\left(A_{s o l, j}\right)$ for each orientation $j$, considering the product of window areas, correction factors and g-values.

\subsection{Case-Study Area}

The regional building stock energy model is similar to that applied nationally in [33] but downscaled to the Metropolitan Area of Lisbon (Área Metropolitana de Lisboa, hereafter AML), taking into account a total of 242,860 energy performance certificates of new and existing residential building units. AML covers $3000 \mathrm{~km}^{2}$ (Figure 2) and has a population of 2.86 million. It includes two NUTS III regions, corresponding to North and South of Tagus riverside regions (Figure 2), hereafter North-AML and South-AML ('Grande Lisboa' and 'Península de Setúbal', respectively). The total number of building units in this area is about 1.5 million, and $75 \%$ of them are regularly occupied (Table 3). EPC data represent $16 \%$ of the total building units, a considerable large sample of the building stock. 


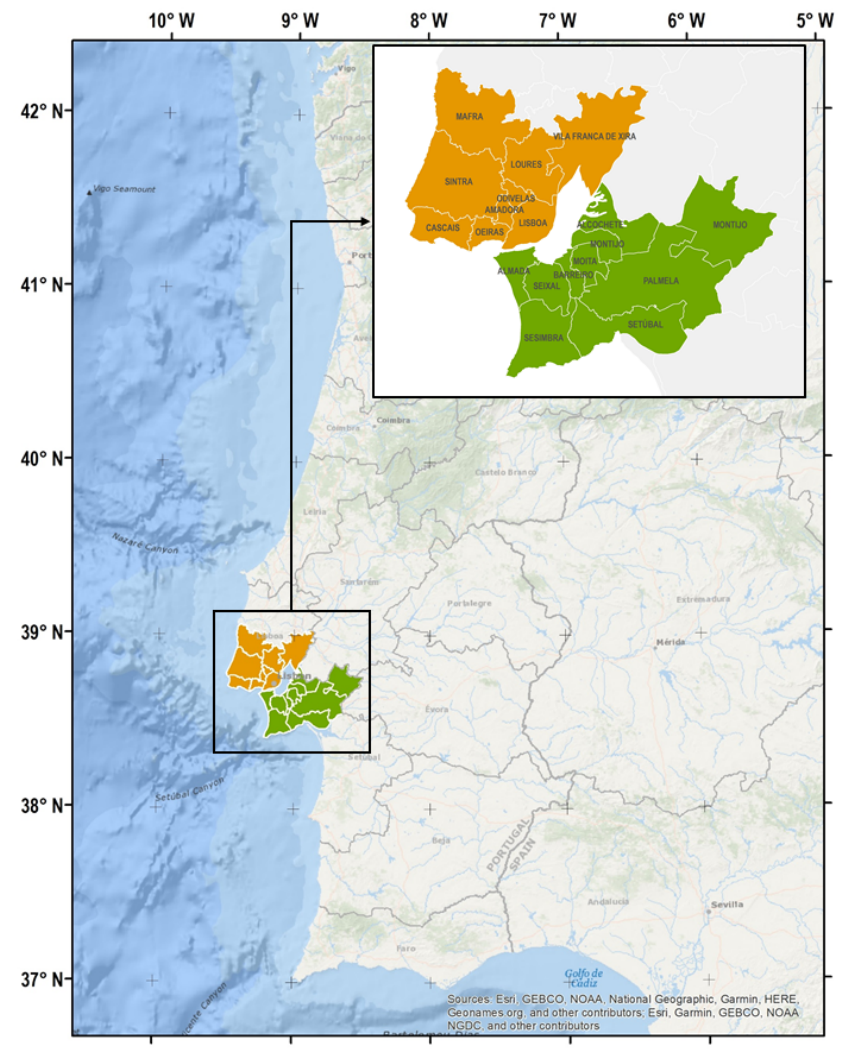

Figure 2. Metropolitan Area of Lisbon (AML) according to NUTS II classification and subdivision of Portuguese territory. NUTS III regions: North AML (orange) and South AML (green).

Table 3. Building units and all end-use electricity consumption of Metropolitan Area of Lisbon (AML).

\begin{tabular}{|c|c|c|c|c|}
\hline Data Source & & 2011 & 2015 & 2020 \\
\hline \multirow[t]{4}{*}{ Census [37] } & $\begin{array}{l}\text { Residential building } \\
\text { units }\end{array}$ & $1,487,098$ & & \\
\hline & $\begin{array}{l}\text { Units regularly } \\
\text { occupied }\end{array}$ & $1,129,789$ & & \\
\hline & $\begin{array}{l}\text { Units with heating } \\
\text { equipment }\end{array}$ & 956,955 & & \\
\hline & $\begin{array}{l}\text { Units with electric } \\
\text { heating equipment }\end{array}$ & 750,412 & & \\
\hline \multirow[t]{2}{*}{$\begin{array}{l}\text { Households Budget } \\
\text { Survey [38] }\end{array}$} & $\begin{array}{l}\text { Units regularly } \\
\text { occupied }\end{array}$ & & $1,156,539$ & \\
\hline & Units with heat pumps & & 180,581 & \\
\hline \multirow[t]{3}{*}{$\begin{array}{c}\text { Directorate General for } \\
\text { Energy and } \\
\text { Geology [39] }\end{array}$} & $\begin{array}{l}\text { Residential electricity } \\
\text { contracts }\end{array}$ & $1,449,911$ & $1,408,733$ & $1,505,847$ \\
\hline & $\begin{array}{l}\text { Residential electricity } \\
\text { consumption }[\mathrm{GWh} / \mathrm{y}]\end{array}$ & 3558 & 3135 & 3413 \\
\hline & $\begin{array}{c}\text { Mean electricity } \\
\text { consumption }[\mathrm{kWh} / \mathrm{y}]\end{array}$ & 2454 & 2226 & 2266 \\
\hline
\end{tabular}

Building units not regularly occupied with an electricity contract still use electricity (e.g., refrigerator, freezer, other appliances), even if the electricity might be much lower than those that are regularly occupied. Considering not regularly occupied units explains the mean electricity consumption (e.g., $2226 \mathrm{kWh} / \mathrm{y}$ in 2015) being lower than values obtained from smart metering (e.g., for Lisbon city $3927 \mathrm{kWh} / \mathrm{y}$ in 2015-2016 [33]) and the data 
reported by the two national surveys on the residential energy consumption [40,41] (for national territory $3674 \mathrm{kWh} / \mathrm{y}$ in 2010 and $3360 \mathrm{kWh} / \mathrm{y}$ in 2020).

This study focuses on the building stock electricity consumption for space heating and cooling. For that reason, it excludes other heating systems (gas burners, boilers, fireplaces, etc.) still used in about $18 \%$ of the regularly occupied units (data from 2011). Since there are no available regional disaggregated data, the best knowledge comes from the 2010 national survey on household energy consumption [40] that estimated mean electricity consumption $333 \mathrm{kWh} / \mathrm{y}$ for space heating and $59 \mathrm{kWh} / \mathrm{y}$ for space cooling. According to the preliminary results of the updated survey for 2020 [41], this figure for heating decreased to $138 \mathrm{kWh} / \mathrm{y}$. No information is available for cooling. It is noteworthy that the percentage of AML regularly occupied units with resistive heating equipment represented, in 2011, $51 \%$ [37] and those with heat pumps (including air conditioning units) for heating and cooling, in 2015, represented 16\% [38].

Distributions in Table 4 are direct outputs of the tool [35] applied to AML and support the generation of some of the building form and fabric parameters. Since no regional differences for other form and fabric parameters are expected, the independent distributions already applied in [33] are kept invariant.

Table 4. Independent probability distributions for building form and fabric.

\begin{tabular}{cc}
\hline Model Parameter & Probability Distribution \\
\hline Net floor area $\left[\mathrm{m}^{2}\right]$ & Generalized extreme value $(\mathrm{a}=0.204$, \\
& $\mathrm{b}=29.284, \mathrm{c}=65.29)$ \\
Air infiltration rate $[\mathrm{ach}]$ & $\mathrm{c}=0.464)$ \\
\hline
\end{tabular}

\subsection{User Profiles}

EPC data do not contain enough information to generate user profiles, but those are critical to computing electricity consumption. To that end, different data sources support the model inputs selection. The first set of conditions regards occupancy patterns, temperature set-points, heating and cooling time of use and heated and cooled floor area. Four scenarios regarding how users interact with their houses and equipment are explored:

- Nominal conditions (A)-Internal gains are fixed and constant $\left(4 \mathrm{~W} / \mathrm{m}^{2}\right)$, accounting for heat dissipation of occupants, lighting and appliances. Heating/cooling equipment is available during heating/cooling season, whenever air temperature goes below $18^{\circ} \mathrm{C}$ (for heating) and above $25^{\circ} \mathrm{C}$ (for cooling). These assumptions align with those defined by the EPC seasonal approach [42].

- Actual conditions (B)-Internal gains are calculated from occupant's metabolism assuming an occupancy profile that is stochastically generated, based on data collected during a survey study [33]. The same applies to space heated/cooled floor areas and heating/cooling time of use. The number of occupants is obtained from statistics [38] by a probability distribution that generates an integer between 1 and 6 as output, with a mean occupancy of 2.45 per building unit. Heat dissipation by lighting and appliances comes from measured daily mean electricity profiles [33,43], with a mean value of $3 \mathrm{~W} / \mathrm{m}^{2}$ (maximum at 10:30 p.m. and minimum at 5:30 a.m.). Heating and cooling set-points are the minimum (for heating) and the maximum (for cooling) of the air temperature range for living spaces in class II residential buildings, according to EN 15251 [44], 20 and $26^{\circ} \mathrm{C}$, respectively. The conditions mentioned above aim at describing actual conditions to provide an output close to the actual electricity consumption.

- Adequate conditions (C)-Scenario (C) is similar to (B) except for the space heated/ cooled floor area and heating/cooling time of use. Heated and cooled floor area is computed by the minimum room area required by the number of occupants based on $12 \mathrm{~m}^{2}$ per occupant (equivalent to a bedroom or small living room). The use time 
for heating/cooling equipment is the same as the occupancy profile. This scenario provides an estimation of the required electricity consumption to provide adequate thermal comfort conditions.

- Minimum conditions (D) - The scenario (D) is similar to (C), except for heating/cooling set-points. Heating and cooling set-points are the minimum (for heating) and the maximum (for cooling) of the air temperature range for living spaces in class III residential buildings [44], 18 and $27^{\circ} \mathrm{C}$, respectively. This scenario provides an estimation of the required electricity consumption to provide minimum thermal comfort conditions.

A summary of scenarios (A) to (D) is presented in Table 5. A user profile is randomly generated for each building unit for (B) to (D) conditions. For nominal conditions (A), the user profile is the same for all building units.

Table 5. Conditions to generate user profiles: Model inputs and assumptions.

\begin{tabular}{|c|c|c|}
\hline Model Conditions & Model Inputs & Model Assumptions \\
\hline \multirow[t]{12}{*}{ A-Nominal conditions } & Occupants, lighting and appliances & continuous, $4 \mathrm{~W} / \mathrm{m}^{2}$ \\
\hline & Space heating set-point & $18^{\circ} \mathrm{C}$ \\
\hline & Space cooling set-point & $25^{\circ} \mathrm{C}$ \\
\hline & Fraction of heated floor area & 1 \\
\hline & Fraction of cooled floor area & 1 \\
\hline & $\begin{array}{c}\text { Time of use of heating and cooling } \\
\text { systems }\end{array}$ & always \\
\hline & Units with resistive heating and efficiency & $50.8 \%, \eta=1$ \\
\hline & $\begin{array}{l}\text { Units with heat pumps for heating and } \\
\text { COP }\end{array}$ & $15.6 \%$, Weibull $(\lambda=3.601, \kappa=5.267)$ \\
\hline & $\begin{array}{l}\text { Units with heat pumps for cooling and } \\
\text { EER }\end{array}$ & $\begin{array}{c}15.6 \%, \operatorname{Burr}(\lambda=2.581, \kappa=14.336 \\
v=0.686)\end{array}$ \\
\hline & Units with other heating equipment & $18.3 \%$ (no electricity consumption) \\
\hline & Units without heating equipment & $15.3 \%$ (default, $\eta=1)$ \\
\hline & Units without cooling equipment & $84.4 \%$ (default, EER 3.0) \\
\hline \multirow[t]{10}{*}{$\begin{array}{l}\text { B-Actual conditions } \\
\text { (same as A except for) }\end{array}$} & Number of occupants & $\begin{array}{c}1(24.3 \%), 2(33.1 \%), 3(22.1 \%), 4(15.0 \%), \\
5(4.3 \%), 6(1.2 \%)\end{array}$ \\
\hline & Occupation profile & weekdays and weekend profiles [33] \\
\hline & Lighting and appliances & daily profile $[33,43]$ \\
\hline & Space heating set-point & $20^{\circ} \mathrm{C}$ \\
\hline & Space cooling set-point & $26^{\circ} \mathrm{C}$ \\
\hline & Fraction of heated floor area & Weibull $(\lambda=0.490, \kappa=1.704)$ \\
\hline & Fraction of cooled floor area & Weibull $(\lambda=0.415, \kappa=1.619)$ \\
\hline & $\begin{array}{c}\text { Time of use of heating and cooling } \\
\text { systems }\end{array}$ & weekdays and weekend profiles [33] \\
\hline & Units without heating equipment & $15.3 \%$ (no electricity consumption) \\
\hline & Units without cooling equipment & $84.4 \%$ (no electricity consumption) \\
\hline \multirow[t]{4}{*}{$\begin{array}{l}\text { C-Adequate conditions } \\
\text { (same as B except for) }\end{array}$} & Heated and cooled floor area & $12 \mathrm{~m}^{2}$ per occupant \\
\hline & $\begin{array}{c}\text { Time of use of heating and cooling } \\
\text { systems }\end{array}$ & occupied hours \\
\hline & Units without heating equipment & $15.3 \%$ (default, $\eta=1$ ) \\
\hline & Units without cooling equipment & $84.4 \%$ (default, EER 2.9) \\
\hline \multirow[t]{2}{*}{$\begin{array}{l}\text { D-Minimum conditions } \\
\text { (same as C except for) }\end{array}$} & Space heating set-point & $18^{\circ} \mathrm{C}$ \\
\hline & Space cooling set-point & $27^{\circ} \mathrm{C}$ \\
\hline
\end{tabular}

Calculating the building stock total electricity consumption under actual conditions (B) assumes no electricity consumption for building units without heating or cooling equipment, which are $15.3 \%$ and $84.4 \%$, respectively. On the other hand, for scenarios (A), (C) and (D), potential electricity consumption is additionally calculated assuming a default equipment, which are resistive heating and a heat pump for cooling. Default EER values 
are 2.9 (the mean value of the generated distribution) for (C) and (D) and 3.0 (the EPC default) for (A). For all scenarios, no electricity consumption is accounted for the building units that use other energy sources for heating. For heating and cooling, the heat pump performance is stochastically obtained by the independent distributions obtained for AML building units [35].

\subsection{Energy Needs Calculation}

Two different approaches are used to calculate space heating and cooling energy needs: quasi-steady-state on a seasonal basis (seasonal steady-state) and RC model on an hourly basis (hourly RC). Despite inputs being similar, approaches significantly differ in considering transient heat processes.

The first considers thermal inertia by including an empirical input-the utilization gain factor $\eta_{g}$ - which is a function of $\gamma$, the ratio between heat transfer $\left(Q_{h t}\right)$ and heat gains $\left(Q_{g n}\right)$. Heat transfer and heat gains are energy values integrated during the calculation period (heating or cooling season). The computation of heat transfer and heat gains might include simplifications. Heating and cooling energy needs are obtained, respectively, from:

$$
\begin{gathered}
Q_{n d, H}=Q_{h t}-\eta_{g} Q_{g n} \\
Q_{n d, C}=\left(1-\eta_{g}\right) Q_{g n}
\end{gathered}
$$

The equations to compute heat transfer, heat gains and gain utilization factor follow EN ISO 13790 [45] considering the simplifications and assumptions of the EPC approved method in Portugal [42]. It is noteworthy that energy needs on the EPC database were calculated by the seasonal steady-state method, and that is the reason why EN ISO 13790 is still used, even if it was revised and replaced by ISO 52016 [46]. The latter does not include the seasonal approach but only the monthly approach.

The second approach uses thermal inertia, simplifying the building unit to a lumped single heat capacitance (5R1C) [47]. The thermal grid includes five thermal resistancesexpressed as the inverse of the thermal conductances-connecting the thermal nodes (Figure 3): outdoor air, $\theta_{e}$, supplying ventilation air, $\theta_{v}$ (if different from outdoor), and indoor, $\theta_{i}$. Heavy and light elements are separately modeled.

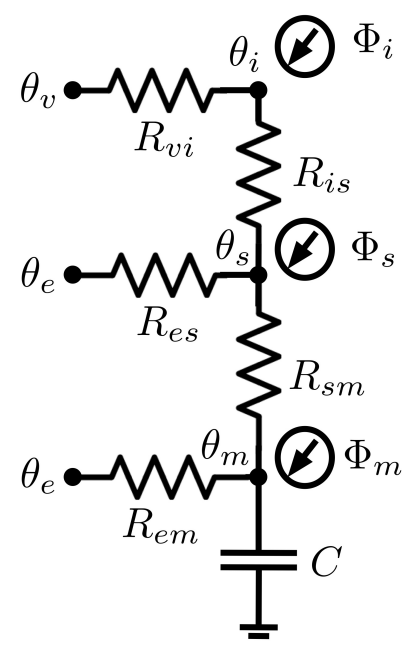

Figure 3. Hourly RC model: Lumped single heat capacitance (5R1C).

The mass temperature, $\theta_{m}$, connects to a lumped thermal capacitance, $C$, modeling the energy storage capability of heavy elements. The star temperature, $\theta_{s}$, is the weighted indoor, outdoor and mass temperatures. Total heat gains are split into nodes $\Phi_{i}, \Phi_{s}$ and $\Phi_{m}$. 
Node energy balance equations are solved by a Cranck-Nicolson scheme with an hourly time-step. For further details on the approaches equations, refer to [45].

Both approaches are simplified and low computational demanding, critical modeling issues when computing energy needs for many building units. Direct outputs of the model are distribution functions for space heating and cooling energy needs (per unit of net floor area). However, for evaluating the building stock, integrated values are as relevant as distributions. For simplicity, the mean value per building unit is adopted as the primary parameter to compare scenarios.

\subsection{Climate Data}

Climate data for the selected region are available on an hourly and seasonal basis for North-AML and South-AML. The energy calculations consider the hourly data of air temperature and façade solar radiation (horizontal, cardinal and ordinal orientations) for the reference altitude of each region [48] (CLM\#2). On the other hand, seasonal climate data used for model validation are those defined by EPC [42] (CLM\#1), considering heating degree-days and mean air temperature corrected to local altitude. Tables 6 and 7 compare the seasonal data (CLM\#1) with the same parameters calculated from the hourly dataset (CLM\#2).

Table 6. Heating season climate parameters.

\begin{tabular}{|c|c|c|c|c|c|}
\hline NUTS III Region & Climate Dataset & $\begin{array}{l}\text { Season Length } \\
\text { [Days] }\end{array}$ & $\begin{array}{c}\text { Heating } \\
\text { Degree-Days } \\
{\left[{ }^{\circ} \mathrm{C} d\right]}\end{array}$ & $\begin{array}{c}\text { Daily South Solar } \\
\text { Radiation } \\
{\left[\mathrm{kWh} / \mathrm{m}^{2}\right]}\end{array}$ & $\begin{array}{c}\text { Daily Horizontal } \\
\text { Solar Radiation } \\
{\left[\mathrm{kWh} / \mathrm{m}^{2}\right]}\end{array}$ \\
\hline \multirow[t]{3}{*}{ North-AML } & $\# 1$ & 159 & $1033^{a}$ & 5.00 & 4.45 \\
\hline & \#2 & 159 & 874 & 3.67 & 3.63 \\
\hline & $(\# 1-\# 2) / \# 2$ & - & $-15 \%$ & $-27 \%$ & $-18 \%$ \\
\hline \multirow[t]{3}{*}{ South-AML } & $\# 1$ & 141 & $1034^{\mathrm{a}}$ & 4.83 & 4.30 \\
\hline & $\# 2$ & 139 & 790 & 3.65 & 3.19 \\
\hline & $(\# 1-\# 2) / \# 2$ & $-1 \%$ & $-24 \%$ & $-32 \%$ & $-26 \%$ \\
\hline
\end{tabular}

${ }^{a}$ Mean value of the probability distribution that accounts for the local altitude.

Table 7. Cooling season climate parameters.

\begin{tabular}{|c|c|c|c|c|c|}
\hline NUTS III Region & Climate Dataset & $\begin{array}{l}\text { Season Length } \\
\text { [Days] }\end{array}$ & $\begin{array}{c}\text { Mean Air } \\
\text { Temperature }\left[{ }^{\circ} \mathrm{C}\right]\end{array}$ & $\begin{array}{c}\text { Daily South Solar } \\
\text { Radiation } \\
{\left[\mathrm{kWh} / \mathrm{m}^{2}\right]}\end{array}$ & $\begin{array}{c}\text { Daily Horizontal } \\
\text { Solar Radiation } \\
{\left[\mathrm{kWh} / \mathrm{m}^{2}\right]}\end{array}$ \\
\hline \multirow[t]{3}{*}{ North-AML } & $\# 1$ & 122 & $22.8^{a}$ & 3.36 & 6.88 \\
\hline & $\# 2$ & 122 & $22.8^{\mathrm{a}}$ & 3.34 & 6.83 \\
\hline & $(\# 1-\# 2) / \# 2$ & - & - & $-1 \%$ & $-1 \%$ \\
\hline \multirow[t]{3}{*}{ South-AML } & $\# 1$ & 122 & $21.9^{\mathrm{a}}$ & 3.36 & 6.93 \\
\hline & $\# 2$ & 122 & 21.7 & 3.29 & 6.87 \\
\hline & $(\# 1-\# 2) / \# 2$ & - & $-1 \%$ & $-2 \%$ & $-1 \%$ \\
\hline
\end{tabular}

${ }^{a}$ Mean value of the probability distribution that accounts for the local altitude.

The main differences between climate datasets are found for heating degree-days and winter daily solar radiation (Table 6). The calculated parameters for CLM\#2 are $15 \%$ to $32 \%$ lower than the tabulated CLM\#1. The most probable explanation for these differences is that CLM\#1 inadvertently refers to an 8-month season (from October to May) instead of considering a variable heating season. The hourly model uses a shorter heating season, agreeing with the heating season length of 159 days (5.3 months) for North-AML and 139 days (4.6 months) for South-AML, both starting on the last days of November. The heating season for CLM\#2, in agreement with [49], begins on the first day of the first 15-day period with a daily mean air temperature not above $15^{\circ} \mathrm{C}$ and it ends on the last 15-day period with values not below $15^{\circ} \mathrm{C}$. Fewer heat gains during winter may counterbalance 
fewer heat losses due to the decrease in heating degree-days and daily solar radiation of CLM\#2. No significant differences are found for the cooling season (Table 7).

\section{Results Analysis and Discussion}

The study purposes are fourfold (Figure 1). The results and discussion are structured accordingly:

1. Validate the building stock model validation (Section 3.1);

2. Compare hourly and seasonal methods (Section 3.2);

3. Compare actual electricity consumption with average data from statistics (Section 3.3.2);

4. Compare calculated electricity consumption for adequate and minimum conditions with the calculated for actual conditions (Section 3.3.3).

\subsection{Building Stock Model Validation}

The EPC dataset includes the building form and fabric parameters as well as heating and cooling energy needs. However, not all the parameters required to compute energy needs are collected. The stochastic generation of the building stock is validated by comparing the calculated energy needs for the theoretical sample with those collected by EPC. Energy calculations use CLM\#1 climate data since they are set for EPC calculations. Furthermore, the same methodological simplifications are applied. For example, the EPC method does not consider heat transfer through the envelope separating the net volume from the non-heated spaces for cooling energy calculation or solar gains through the opaque envelope for heating energy calculation. Since the goal is to model the building stock of the case study area, convergence between the obtained and the EPC distributions is expected. The comparison uses three parameters: the distribution median (Q2, second quartile), the first quartile (Q1) and the third quartile (Q3). The stochastic generation depends on the building unit sample, $N$, which should be large enough to represent the building stock. Therefore, model validation includes a sensitivity evaluation of $N$.

The results show that generating more than $10^{5}$ building units is enough to keep almost invariable RMSEs and the relative differences Q1, Q2 and Q3 between the calculated energy needs and EPC dataset (Table 8). For $N=10^{6}$, the model generates a building stock with a similar distribution for heating and cooling energy needs (Figure 4), with an RMSE of about $4 \times 10^{-3}$ (16 bins). It performs better for cooling energy needs, where the relative differences from Q1 to Q3 are in the range of $\pm 2 \%$, than for heating energy needs, where the same relative differences are in the range $\pm 6 \%$.

Table 8. Model validation: RMSE and relative differences of calculated energy needs compared to the EPC dataset.

\begin{tabular}{cccccc}
\hline $\begin{array}{c}\text { Sample } \\
\boldsymbol{N}\end{array}$ & RMSE & \multicolumn{4}{c}{ Relative Difference [\%] } \\
$\mathbf{( 1 6}$ Bins) & Q1 & Q2 & Q3 & Mean \\
\hline Heating & & & & -9.2 & -3.5 \\
\hline $10^{3}$ & $4.91 \times 10^{-3}$ & 1.3 & -7.7 & -5.4 & -0.9 \\
$10^{4}$ & $4.00 \times 10^{-3}$ & 2.2 & -6.3 & -5.5 & -1.0 \\
$10^{5}$ & $3.96 \times 10^{-3}$ & 1.5 & -6.3 & -5.9 & -1.0 \\
$10^{6}$ & $4.08 \times 10^{-3}$ & 1.7 & -6.5 & -5.8 & -1.0 \\
$10^{7}$ & $4.07 \times 10^{-3}$ & 1.7 & -6.4 & & \\
\hline Cooling & & & & 0.4 & 1.1 \\
\hline $10^{3}$ & $4.12 \times 10^{-3}$ & -3.2 & -3.7 & 4.2 \\
$10^{4}$ & $3.59 \times 10^{-3}$ & -0.9 & -2.1 & 2.0 & 3.0 \\
$10^{5}$ & $3.56 \times 10^{-3}$ & -0.7 & -1.9 & 1.8 & 3.9 \\
$10^{6}$ & $3.77 \times 10^{-3}$ & -1.0 & -2.3 & 1.8 & 3.9 \\
$10^{7}$ & $3.70 \times 10^{-3}$ & -1.0 & -2.2 & & \\
\hline
\end{tabular}




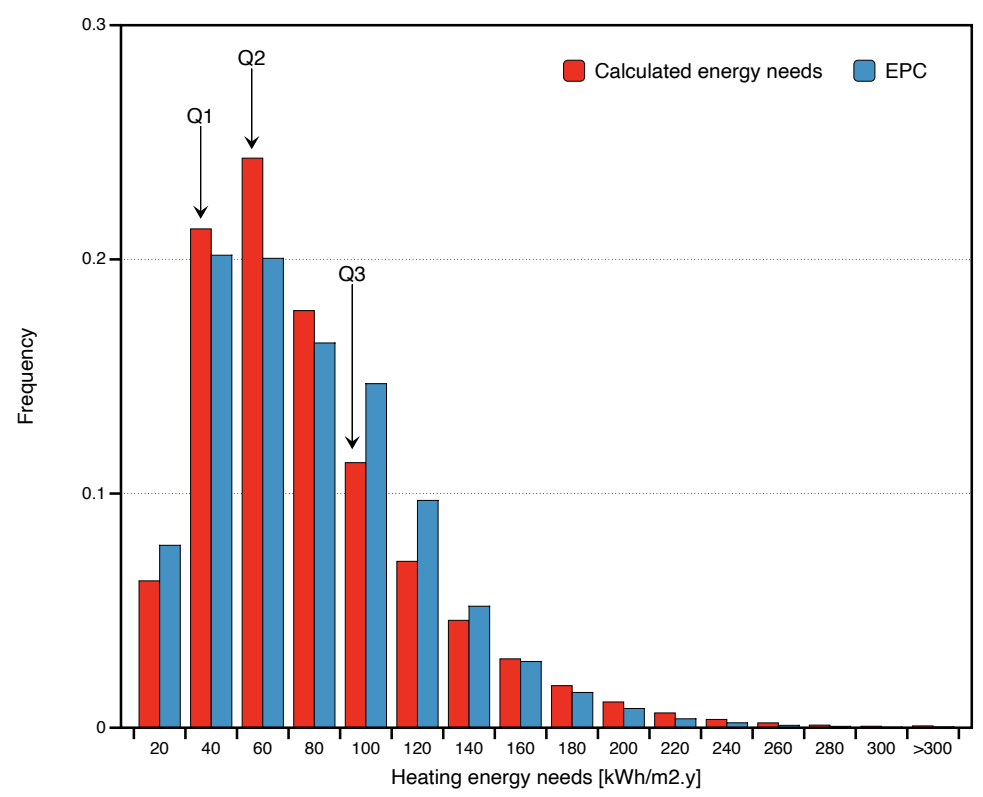

(a)

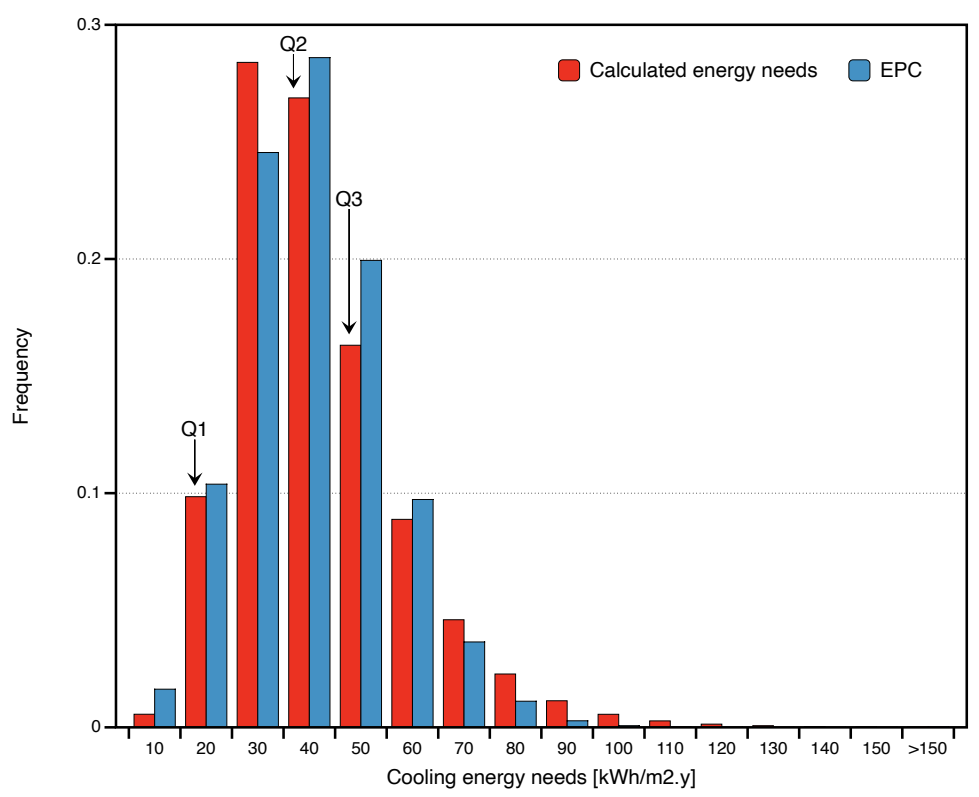

(b)

Figure 4. Calculated energy needs for the generated building-stock $\left(N=10^{6}\right)$ compared with EPC data. The bin interval that contains the median (Q2), first (Q1) and third quartiles (Q3) are identified: (a) Heating energy needs (top); (b) Cooling energy needs (bottom).

\subsection{Energy Calculations: Hourly and Seasonal Methods}

After testing the model potential to generate the building stock, the two energy calculation approaches are compared: (i) the seasonal steady-state and (ii) the hourly RC. Both methods consider CLM\#2 climate data. Considering that the seasonal approach does not apply to intermittent heating/cooling profiles, both approaches are compared under nominal conditions (A). Even if this assumption seems unrealistic, it is justified for better comparison between methods.

The differences in the estimated mean energy needs are $+6 \%$ and $-3 \%$ for heating and cooling, respectively (Table 9). The distributions for heating energy needs do not significantly differ (Figure 5a). On the other hand, the cooling energy needs calculated by the seasonal steady-state method are significantly lower in the first quarter (Figure 5b), which 
is confirmed by the $15 \%$ relative difference for Q1. Considering the whole distribution, cooling energy needs estimated by the seasonal steady-state are significantly lower in the first quarter, meaning that the hourly approach leads to more building units with energy needs in the range of $0-10 \mathrm{kWh} / \mathrm{m}^{2}$ and less in the range of 10 to $40 \mathrm{kWh} / \mathrm{m}^{2}$.

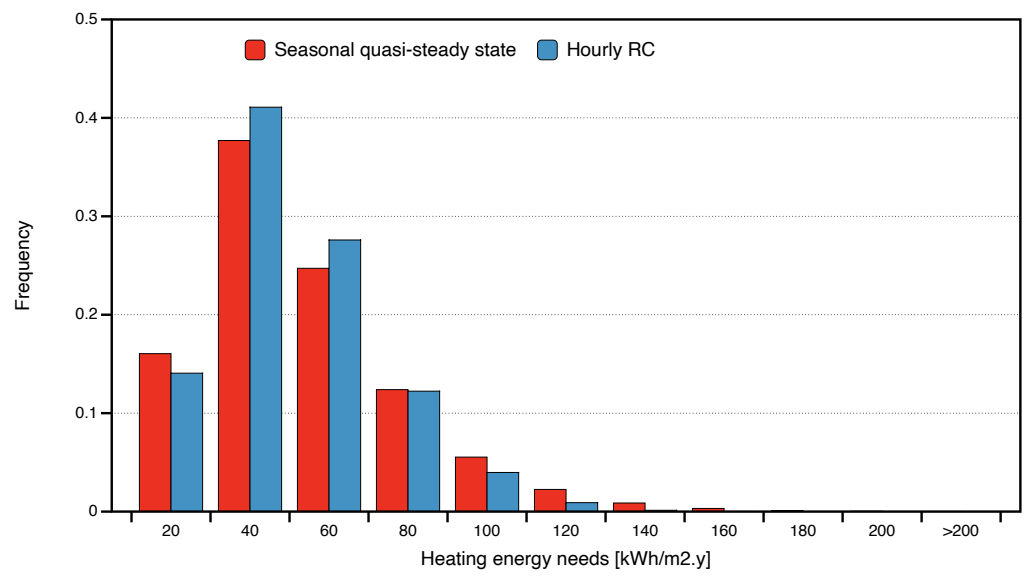

(a)

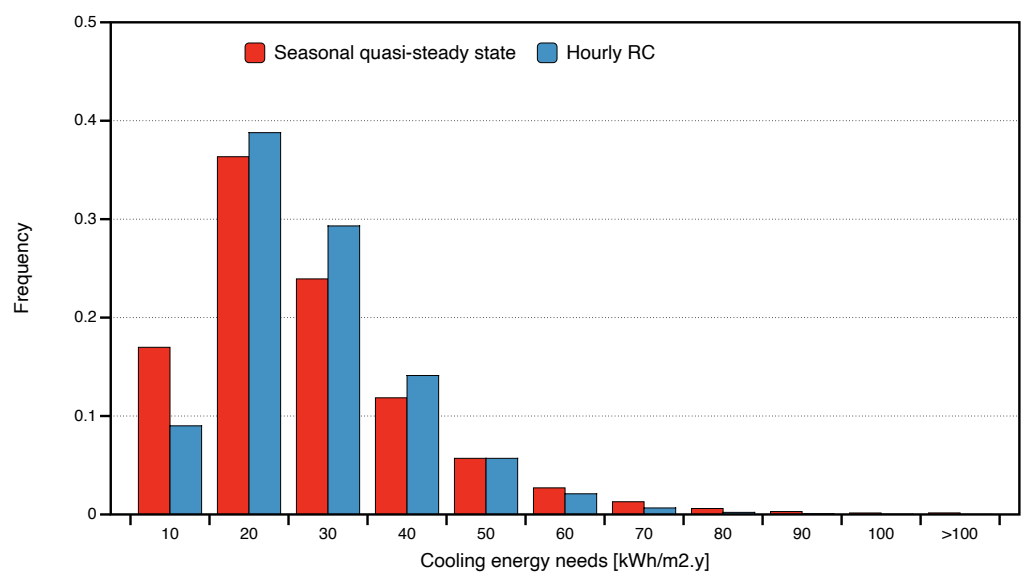

(b)

Figure 5. Calculated energy needs for the generated building-stock $\left(N=10^{6}\right)$ using quasi-steadystate and RC hourly approaches: (a) Heating energy needs (top); (b) Cooling energy needs (bottom).

Table 9. Energy needs calculation $\left(N=10^{6}\right)$ for nominal conditions (A).

\begin{tabular}{ccccc}
\hline $\begin{array}{c}\text { Approach and } \\
\text { Climate Data }\end{array}$ & Q1 $\left[\mathbf{k W h} / \mathbf{m}^{2} \mathbf{y}\right]$ & $\mathbf{Q 2}\left[\mathbf{k W h} / \mathbf{m}^{2} \mathbf{y}\right]$ & $\mathbf{Q 3}\left[\mathbf{k W h} / \mathbf{m}^{2} \mathbf{y}\right]$ & Mean $[\mathbf{k W h} \mathbf{y}]$ \\
\hline Heating & & & & \\
\hline $\mathrm{H} 2$ & 25.6 & 37.3 & 52.8 & 3662 \\
$\mathrm{~S} 2$ & 24.7 & 37.8 & 56.3 & 3883 \\
$\mathrm{~S} 1$ & 37.9 & 58.2 & 88.1 & 6132 \\
$(\mathrm{~S} 2-\mathrm{H} 2) / \mathrm{H} 2$ & $-3 \%$ & $+1 \%$ & $+7 \%$ & $+6 \%$ \\
$(\mathrm{~S} 1-\mathrm{S} 2) / \mathrm{S} 2$ & $+54 \%$ & $+54 \%$ & $+56 \%$ & $+66 \%$ \\
\hline Cooling & & & & \\
\hline $\mathrm{H} 2$ & 14.3 & 20.6 & 29.0 & 2001 \\
$\mathrm{~S} 2$ & 12.2 & 19.0 & 28.7 & 3316 \\
$\mathrm{~S} 1$ & 25.6 & 33.7 & 45.0 & $-3 \%$ \\
$(\mathrm{~S} 2-\mathrm{H} 2) / \mathrm{H} 2$ & $-15 \%$ & $-8 \%$ & $-1 \%$ & $+58 \%$ \\
$(\mathrm{~S} 1-\mathrm{S} 2) / \mathrm{S} 2$ & $+110 \%$ & $+78 \%$ & $+57 \%$ & \\
\hline
\end{tabular}


This study also compares the energy needs considering EPC assumptions (method and climate data) and the alternative approach. The first uses the seasonal approach with some simplifications and CLM\#1 data to calculate the EPC indicators. The second still uses the seasonal approach but considers the hourly heat transfer and heat gains computed terms (no simplifications) and CLM\#2 data.

For the seasonal steady-state approach with simplifications and using CLM\#1 (S1), energy needs are much higher than the same approach without simplifications and CLM\#2 (S2). The mean values increase by $66 \%$ for heating and by $58 \%$ for cooling (Table 9 ). The main conclusion is that EPC energy needs are highly overestimated by more than $50 \%$. Differences are mainly explained by simplifications assumed during heat transfer and heat gains calculation. Furthermore, climate data might influence the results for heating only.

It is expected that this conclusion also applies to other detailed simulation tools using hourly climate data series, making EPC energy needs a weak indicator of actual energy demand. Nevertheless, the EPC method is still valid for labeling since the calculated values compare with the obtained for a reference building in the same conditions.

\subsection{User Profiles and Heating/Cooling Electricity Consumption}

The evaluation of energy needs should be considered an intermediate stage since the model aims to estimate space heating and cooling electricity consumption. To compute it, the model additionally considers the heated/cooled floor area, the equipment efficiency (or heat pump performance) and the number of occupied units with electric equipment. For building units without heating/cooling equipment, the model also calculates a potential electricity consumption applying the default solutions (see details in Table 5).

\subsubsection{Energy Needs}

Energy needs correspond to the required thermal energy; therefore, equipment type and performance do not apply. On the contrary of nominal conditions (A) that consider the same user profile, for scenarios (B) to (D), the model calculates heating and cooling energy needs considering a theoretical sample of $10^{6}$ building units and the equivalent number of randomly generated user profiles. The number of heated/cooled hours decreases from nominal conditions (A) to scenarios (B) to (D). Actual conditions (B) only consider heating and cooling during the hours people answered they effectively use the equipment, while (C) and (D) heating and cooling hours correspond to those occupied.

For all scenarios, heating and cooling energy needs are calculated for the net floor area, i.e., all rooms are heated/cooled. Comparing results from scenario $(C)$ with the obtained applying actual conditions (B) is a measure of the impact of extending the heating/cooling hours to the occupied hours. As a result, mean energy needs for heating increase $70 \%$ and $115 \%$ for cooling (Table 10). Modifying the heating and cooling set-point temperatures to less restrictive thermal comfort conditions-scenario (D)_result in a lower increase, even if mean energy needs are still higher than (B): 17\% for heating and 57\% for cooling (Table 10). These results indicate that the number of hours people use heating and cooling equipment is below the expected number to provide adequate thermal comfort.

Table 10. Energy needs $\left(N=10^{6}\right)$ for the hourly method using climate data CLM\#2. The mean considers that all rooms are heated/cooled.

\begin{tabular}{ccccc}
\hline Scenarios & $\mathbf{Q 1}\left[\mathbf{k W h} / \mathbf{m}^{2} \mathbf{y}\right]$ & $\mathbf{Q} 2\left[\mathbf{k W h} / \mathbf{m}^{2} \mathbf{y}\right]$ & $\mathbf{Q 3}\left[\mathbf{k W h} / \mathbf{m}^{2} \mathbf{y}\right]$ & Mean $[\mathbf{k W h} / \mathbf{y}]$ \\
\hline Heating & \multicolumn{5}{c}{} \\
\hline A & 25.6 & 37.3 & 52.8 & 3662 \\
B & 9.5 & 16.3 & 27.7 & 1897 \\
C & 21.7 & 31.5 & 44.3 & 3230 \\
D & 13.0 & 20.8 & 31.3 & 2228 \\
(C-B)/B & $128 \%$ & $93 \%$ & $60 \%$ & $70 \%$ \\
(D-B)/B & $37 \%$ & $28 \%$ & $13 \%$ & $17 \%$ \\
\hline
\end{tabular}


Table 10. Cont.

\begin{tabular}{ccccc}
\hline Scenarios & Q1 $\left[\mathbf{k W h} / \mathbf{m}^{2} \mathbf{y}\right]$ & $\mathbf{Q} 2\left[\mathbf{k W h} / \mathbf{m}^{2} \mathbf{y}\right]$ & $\mathbf{Q 3}\left[\mathbf{k W h} / \mathbf{m}^{2} \mathbf{y}\right]$ & Mean $[\mathbf{k W h} / \mathbf{y}]$ \\
\hline Cooling & & & & \\
\hline A & 14.3 & 20.6 & 29.0 & 2053 \\
B & 2.6 & 6.6 & 11.7 & 682 \\
C & 10.2 & 15.5 & 22.2 & 1466 \\
D & 6.3 & 11.0 & 17.0 & 1074 \\
$($ C-B $/$ B & $292 \%$ & $135 \%$ & $90 \%$ & $115 \%$ \\
(D-B)/B & $142 \%$ & $67 \%$ & $45 \%$ & $57 \%$ \\
\hline
\end{tabular}

\subsubsection{Actual Conditions and Average Data from Statistics}

Energy needs help to compare the thermal quality of the building stock (e.g., level of thermal insulation, solar gains exposure, air tightness). Still, they are insufficient to assess the electricity consumption for space heating and cooling. The latter also depends on the occupancy level, how people interact with heating and cooling systems, their thermal comfort preferences and their availability to pay for energy. Therefore, the model calculates the electricity consumption for building units with heating/cooling equipment, considering a partial use of heating/cooling equipment for a fraction of the net floor area.

The mean electricity consumption for space heating and cooling is computed considering: (i) all regularly occupied building units and (ii) all regularly occupied building units that have electric heating equipment (resistive heating or heat pump). A similar procedure is implemented for space cooling. The results in Table 11 show that the computed mean electricity consumption for heating under actual conditions (B), $444 \mathrm{kWh} / \mathrm{y}$, is, in fact, higher than the mean value for national territory ( $333 \mathrm{kWh} / \mathrm{y}$ in 2010 and $138 \mathrm{kWh} / \mathrm{y}$ in 2020). Table 11 does not show values normalized per unit of floor area since scenarios differ on the heated/cooled floor area.

Table 11. Mean electricity consumption for space heating and cooling.

\begin{tabular}{|c|c|c|c|c|}
\hline \multirow[b]{2}{*}{$\begin{array}{c}\text { Model } \\
\text { Conditions }\end{array}$} & \multicolumn{4}{|c|}{ Mean Electricity Consumption [kWh/y] } \\
\hline & (A) & (B) & (C) & (D) \\
\hline \multicolumn{5}{|l|}{ Heating } \\
\hline $\begin{array}{c}\text { All regularly } \\
\text { occupied units }{ }^{1}\end{array}$ & 893 & 444 & 566 & 385 \\
\hline $\begin{array}{l}\text { Units having } \\
\text { electric heating } \\
\text { equipment }^{2}\end{array}$ & 1188 & 610 & 753 & 512 \\
\hline \multicolumn{5}{|l|}{ Cooling } \\
\hline $\begin{array}{c}\text { All regularly } \\
\text { occupied units }{ }^{1}\end{array}$ & 34 & 12 & 22 & 16 \\
\hline $\begin{array}{l}\text { Units having } \\
\text { electric cooling } \\
\text { equipment }^{3}\end{array}$ & 270 & 108 & 173 & 129 \\
\hline
\end{tabular}

Building stock aggregated values consider the regularly occupied building units (about 1.16 million in 2015, Table 3). The calculated electricity for heating and cooling compares with all end-use electricity consumption of the case study area, which is $3135 \mathrm{GWh} / \mathrm{y}$ (2015, Table 3). This figure corresponds to the residential building electricity consumption, including regularly and not regularly occupied building units. Knowing that electricity consumption of not regularly occupied units may be lower but not null, and it can be inferred that the mean electricity consumption is somewhere in the interval $2226-2711 \mathrm{kWh} / \mathrm{y}$, below the obtained from smart metering [33] and national surveys [37,41]. 
The results show that the computed electricity for space heating in actual conditions (B) represents $17 \%$ of the overall building stock electricity consumption (Figure 6), which is above the accounted consumption in 2010 and 2020 national surveys, 9.1\% [40] and $4.1 \%$ [41], respectively. As expected, this figure does not account for the electricity consumption of building units without heating equipment $(15.3 \%)$ and those using other non-electric equipment $(18.3 \%)$.

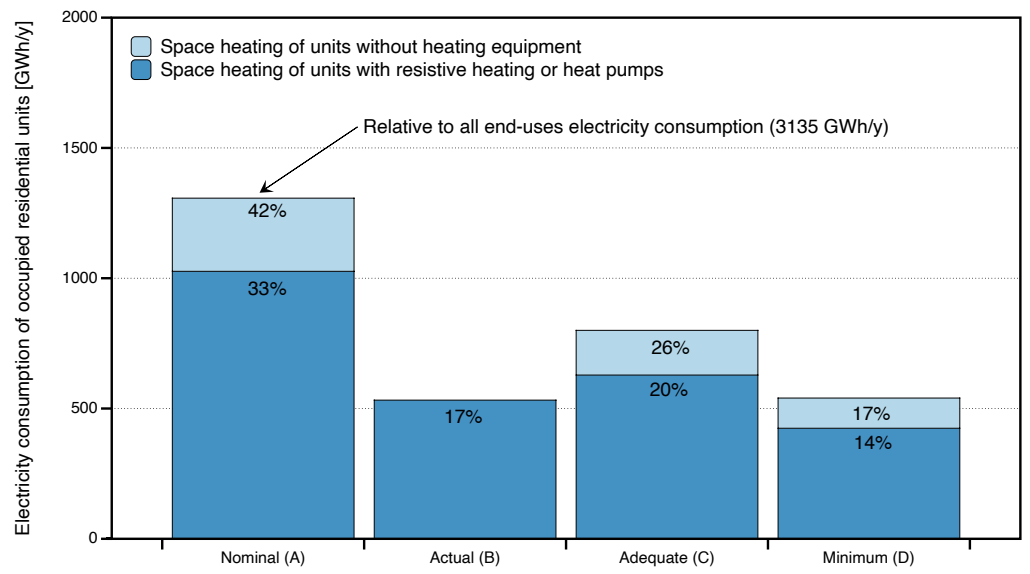

(a)

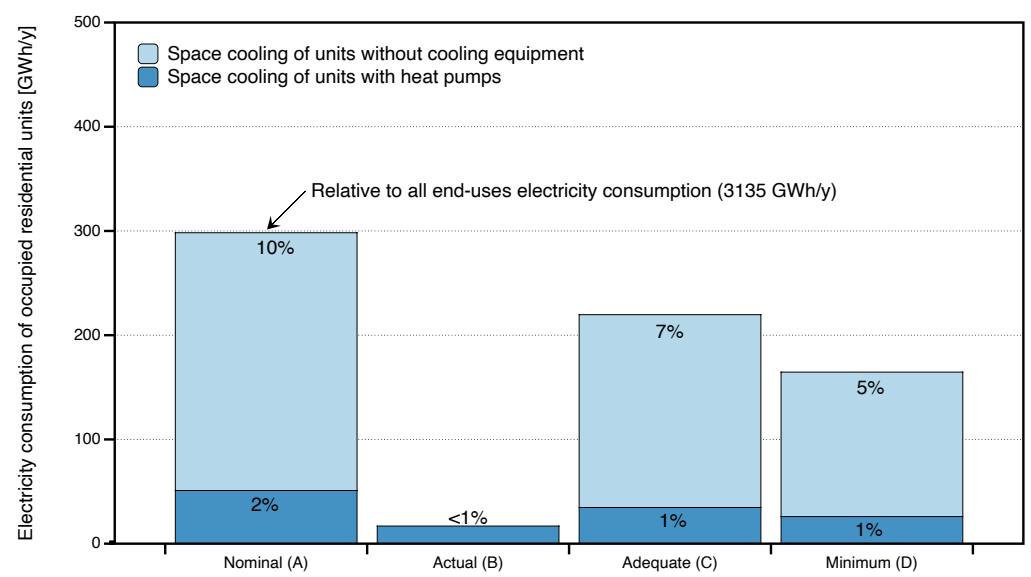

(b)

Figure 6. Calculated electricity consumption in regularly occupied units in AML: (a) space heating (top) and (b) space cooling (bottom).

The procedure to set model inputs is collecting the best available information from statistics and surveys. Even if scenario (B) intends to represent actual conditions, the lack of reliable data on electricity consumption for space heating and cooling makes the model validation for estimating the energy demand impossible. Nevertheless, the results are still a rough approximation of the electricity consumption for the space heating and cooling of AML building stock.

\subsubsection{Actual, Adequate and Minimum Conditions}

To understand if the used electricity is enough to keep thermal comfort conditions, it is relevant to compare the actual conditions scenario with alternative theoretical scenarios that compute the required electricity consumption to achieve thermal comfort conditions without changing the equipment.

The results in Table 11 show that the computed electricity consumption for space heating under actual conditions (B) is in between scenarios (C) and (D), which represent the 'adequate' and the 'minimum' thermal comfort conditions, respectively. On the other 
hand, actual conditions (B) result in the lowest electricity consumption of all scenarios for space cooling.

For scenario (C), the model calculates a heating electricity share of $20 \%$. The figure increases to $26 \%$ by adding the potential electricity consumption of building units without heating equipment, where the default solution is applied (resistive heating). On the other hand, assuming nominal conditions for building units with electric equipment leads to a share of $33 \%$ for space heating.

The results of scenarios (B) and (C) show that the electricity consumption for heating under actual conditions does not ensure adequate thermal comfort in all building units having electric equipment. This conclusion is even more evident for building units without heating equipment. A low mean value reveals a potentially high number of building units where the heated floor area or the heating hours are well below the required for good thermal comfort. Both situations represent a heating gap potentially caused by energy poverty conditions [25].

Making use of the distribution information, we have applied the following procedure to quantify the number of building units with a lower than expected electricity consumption. Building units were divided into groups according to the expected electricity consumption for adequate thermal comfort conditions during the heating season. It is noteworthy that the energy consumption is a direct function of the building characteristics, the minimum heated floor area (12 $\mathrm{m}^{2}$ per occupant) and the number of occupied hours. Therefore, the selected groups are the five-tenths below the median (Table 12).

Table 12. Building units by electricity consumption intervals.

\begin{tabular}{|c|c|c|c|c|c|c|}
\hline $\begin{array}{c}\text { Model } \\
\text { Conditions }\end{array}$ & $\begin{array}{c}\text { Tenth Applied } \\
\text { to (C) }\end{array}$ & 1st & 2nd & 3 rd & 4th & 5 th \\
\hline Adequate (C) & $\begin{array}{c}\text { Electricity } \\
\text { consumption } \\
\text { for space } \\
\text { heating } \\
{[\mathrm{kWh} / \mathrm{y}]}\end{array}$ & $0-175$ & 175-279 & $279-381$ & $381-488$ & $488-611$ \\
\hline Actual (B) & $\begin{array}{l}\text { Building units } \\
\text { fraction }{ }^{1}\end{array}$ & $45.3 \%$ & $11.8 \%$ & $8.0 \%$ & $6.0 \%$ & $5.1 \%$ \\
\hline $\begin{array}{l}\text { Difference } \\
\text { (B) }-(\mathrm{C})\end{array}$ & & $35.3 \%$ & $1.8 \%$ & $-2.0 \%$ & $-4.0 \%$ & $-4.9 \%$ \\
\hline
\end{tabular}

${ }^{1}$ Do not include units that have other energy sources for space heating.

The results show that there are 4.5 times more building units in the first tenth than expected. The excess corresponds to $35.3 \%$ of building units with low electricity consumption (lower than $175 \mathrm{kWh} / \mathrm{y}$ ). In the second tenth, the excess still exists, $1.8 \%$, which corresponds to building units where the electricity consumption is higher but is still insufficient to ensure adequate thermal comfort conditions. As expected, for higher tenths, there is a deficit of building units. Though it can be concluded that about $37 \%$ of the building units not using any other energy sources have an electricity consumption below the required level to achieve adequate thermal comfort.

For all scenarios, the share of electricity used for space cooling does not exceed $2 \%$. The adequate and minimum conditions lead to an electricity consumption above the estimated under actual conditions. Adding electricity consumption of building units without heat pumps significantly increases the potential electricity consumption. Scenarios (C) and (D) show that the residential building stock cooling gap is very high, which is a direct result of the lack of installed heat pumps. 


\section{Conclusions}

The developed building stock energy model combines the building form and fabric characterization with energy systems and user profiles. Using a decade EPC dataset (2008-2018) and the corresponding probability distribution functions, the model generates a theoretical sample of building units and calculates the electricity consumption for space heating and cooling for the case-study region: the Metropolitan Lisbon Area (AML).

Despite the uncertainty regarding some missing parameters not collected in the EPC process, the building stock model consistently predicts the distribution of energy needs per unit of net floor area with an error lower than $7 \%$ of the first, second and third quartiles. The mean value of heating energy needs per unit of floor area is slightly underestimated by $1 \%$, while the cooling energy needs are overestimated by $3 \%$. This comparison considered the same approach (the seasonal steady-state) and climate dataset (CLM\#1).

A further step was to compare the seasonal steady-state with the hourly RC approach, using the climate dataset CLM\#2, since there is no hourly data for CLM\#1. Relative differences are low for energy needs mean value (per building unit): seasonal steady-state overestimates the heating energy needs by $6 \%$ and underestimates the cooling energy needs by $3 \%$. The study also points out that EPC energy needs are not appropriate to compute energy demand since they are much higher than those calculated by the RC hourly approach in the same conditions.

The study was extended to other scenarios, taking advantage of the model capability of defining hourly profiles different from constant assumptions. The scenario defining actual conditions (built from survey) leads to electricity consumption for space heating, representing $17 \%$ of all end-use electricity consumption (3135 GWh in 2015). For cooling, the estimated value is less than $1 \%$. The mean electricity consumption for the regularly occupied building units group is $444 \mathrm{kWh} / \mathrm{y}$ for space heating; by restricting the group to building units without electric heating equipment, a more appropriate parameter, the mean increases to $610 \mathrm{kWh} / \mathrm{y}$. The same procedure applied to space cooling increases the mean from 12 to $108 \mathrm{kWh} / \mathrm{y}$. In the impossibility of an explicit validation due to lack of available data at the regional scale, the electricity consumption presented here should be taken as indicative approximations.

Two other scenarios were evaluated, assuming different user profiles scenarios for what might be the minimum energy consumption required to ensure adequate and minimum thermal comfort (controlling only indoor air temperature). The results show that the actual electricity consumption for space heating $(610 \mathrm{kWh} / \mathrm{y})$ is close to the minimum (512 kWh/y), indicating a potential number of underheated building units. In addition, with the electricity consumption distributions, it is possible to estimate that $37 \%$ of regularly occupied units are under heated. Due to the lack of installed cooling equipment in building units, the electricity consumption is clearly under the required to ensure thermal comfort.

The building stock energy model here presented consists of an alternative approach to the deterministic models. Its stochastic characteristic helps handle data uncertainty and missing values. Furthermore, it is ready to be fed with more updated EPC datasets (e.g., collected data after 2018) and survey results on user profiling. Future developments should compare model estimates with the electricity consumption for space heating and cooling obtained from statistics and surveys for case-study areas.

Author Contributions: Conceptualization and methodology, M.J.N.O.P. and A.P.; software, A.P.; validation, formal analysis, resources, visualization, writing and editing, M.J.N.O.P. All authors have read and agreed to the published version of the manuscript.

Funding: This research was supported by FCT-UIDB/50019/2020-IDL.

Institutional Review Board Statement: Not applicable.

Informed Consent Statement: Not applicable.

Data Availability Statement: Model output data are available under request. 
Acknowledgments: The authors acknowledge National Energy Agency (ADENE), Instituto Nacional de Estatística (INE), and Fundação para Ciência e Tecnologia (FCT) for the data made available for this study and Cristina Catita for helping with the cartographic image.

Conflicts of Interest: The authors declare no conflict of interest.

\begin{tabular}{|c|c|}
\hline \\
\hline \multicolumn{2}{|c|}{ Abbreviations } \\
\hline AML & Metropolitan Area of Lisbon (Área Metropolitana de Lisboa) \\
\hline BSEM & Building Stock Energy Modeling \\
\hline CLM & Climate dataset \\
\hline COP & Coefficient of Performance \\
\hline EER & Energy Efficiency Ratio \\
\hline EPC & Energy Performance Certificates \\
\hline NCEP & National Energy and Climate Plans \\
\hline NUTS & territorial statistical subdivision \\
\hline $\mathrm{RC}$ & Resistance-Capacitance \\
\hline RMSE & Root Mean Square Error \\
\hline UBEM & Urban Building Energy Modeling \\
\hline
\end{tabular}

\section{References}

1. European Commission. A Renovation Wave for Europe-Greening Our Buildings, Creating Jobs, Improving Lives. Communication from the Commission to the European Parliament, the Council, the European Economic and Social Committee and the Committee of the Regions; European Commission: Brussels, Belgium 2020.

2. Healy, J.D. Excess winter mortality in Europe: A cross country analysis identifying key risk factors. J. Epidemiol. Community Health 2003, 57, 784-789. [CrossRef] [PubMed]

3. Fowler, T.; Southgate, R.J.; Waite, T.; Harrell, R.; Kovats, S.; Bone, A.; Doyle, Y.; Murray, V. Excess winter deaths in Europe: A multi-country descriptive analysis. Eur. J. Public Health 2015, 25, 339-345. [CrossRef] [PubMed]

4. The European Parliament and the Council of the European Union. Regulation (EU) 2018/1999. Available online: http://data. europa.eu/eli/reg/2018/1999/oj (accessed on 7 July 2021).

5. D’Ippoliti, D.; Michelozzi, P.; Marino, C.; de’Donato, F.; Menne, B.; Katsouyanni, K.; Kirchmayer, U.; Analitis, A.; Medina-Ramón, M.; Paldy, A.; et al. The impact of heat waves on mortality in 9 European cities: Results from the EuroHEAT project. Environ. Health 2010, 9, 1-9. [CrossRef] [PubMed]

6. Reinhart, C.F.; Davila, C.C. Urban building energy modeling-A review of a nascent field. Build. Environ. 2016, 97, 196-202. [CrossRef]

7. Hong, T.; Chen, Y.; Luo, X.; Luo, N.; Lee, S.H. Ten questions on urban building energy modeling. Build. Environ. 2020, 168, 106508. [CrossRef]

8. Gassar, A.A.A.; Cha, S.H. Energy prediction techniques for large-scale buildings towards a sustainable built environment: A review. Energy Build. 2020, 224, 110238. [CrossRef]

9. Swan, L.G.; Ugursal, V.I. Modeling of end-use energy consumption in the residential sector: A review of modeling techniques. Renew. Sustain. Energy Rev. 2009, 13, 1819-1835. [CrossRef]

10. Langevin, J.; Reyna, J.L.; Ebrahimigharehbaghi, S.; Sandberg, N.; Fennell, P.; Nägeli, C.; Laverge, J.; Delghust, M.; Mata, É.; Van Hove, M.; et al. Developing a common approach for classifying building stock energy models. Renew. Sustain. Energy Rev. 2020, 133, 110276. [CrossRef]

11. Ahern, C.; Norton, B. Energy Performance Certification: Misassessment due to assuming default heat losses. Energy Build. 2020, 224, 110229. [CrossRef]

12. Sarto, L.; Sanna, N.; Tonetti, V.; Ventura, M. On the use of an energy certification database to create indicators for energy planning purposes: Application in northern Italy. Energy Policy 2015, 85, 207-217.

13. Hjortling, C.; Björk, F.; Berg, M.; af Klintberg, T. Energy mapping of existing building stock in Sweden-Analysis of data from Energy Performance Certificates. Energy Build. 2017, 153, 341-355. [CrossRef]

14. Beagon, P.; Boland, F.; Saffari, M. Closing the gap between simulation and measured energy use in home archetypes. Energy Build. 2020, 224, 110244. [CrossRef]

15. Cozza, S.; Chambers, J.; Deb, C.; Scartezzini, J.L.; Schlüter, A.; Patel, M.K. Do energy performance certificates allow reliable predictions of actual energy consumption and savings? Learning from the Swiss national database. Energy Build. 2020, $224,110235$. [CrossRef]

16. Abela, A.; Hoxley, M.; McGrath, P.; Goodhew, S. An investigation of the appropriateness of current methodologies for energy certification of Mediterranean housing. Energy Build. 2016, 130, 210-218. [CrossRef] 
17. Vivian, J.; Zarrella, A.; Emmi, G.; De Carli, M. An evaluation of the suitability of lumped-capacitance models in calculating energy needs and thermal behaviour of buildings. Energy Build. 2017, 150, 447-465. [CrossRef]

18. Zarrella, A.; Prataviera, E.; Romano, P.; Carnieletto, L.; Vivian, J. Analysis and application of a lumped-capacitance model for urban building energy modelling. Sustain. Cities Soc. 2020, 63, 102450. [CrossRef]

19. Carnieletto, L.; Ferrando, M.; Teso, L.; Sun, K.; Zhang, W.; Causone, F.; Romagnoni, P.; Zarrella, A.; Hong, T. Italian prototype building models for urban scale building performance simulation. Build. Environ. 2021, 192, 107590. [CrossRef]

20. Goy, S.; Coors, V.; Finn, D. Grouping techniques for building stock analysis: A comparative case study. Energy Build. 2021, 236, 110754. [CrossRef]

21. De Jaeger, I.; Lago, J.; Saelens, D. A probabilistic building characterization method for district energy simulations. Energy Build. 2021, 230, 110566. [CrossRef]

22. Sokol, J.; Davila, C.C.; Reinhart, C.F. Validation of a Bayesian-based method for defining residential archetypes in urban building energy models. Energy Build. 2017, 134, 11-24. [CrossRef]

23. Ben, H.; Steemers, K. Modelling energy retrofit using household archetypes. Energy Build. 2020, 224, 110224. [CrossRef]

24. Ben, H.; Steemers, K. Household archetypes and behavioural patterns in UK domestic energy use. Energy Effic. 2018, 11, 761-771. [CrossRef]

25. Panão, M.J.O. Lessons learnt from using energy poverty expenditure-based indicators in a mild winter climate. Energy Build. 2021, 242, 110936. [CrossRef]

26. Horta, A.; Gouveia, J.P.; Schmidt, L.; Sousa, J.C.; Palma, P.; Simões, S. Energy poverty in Portugal: Combining vulnerability mapping with household interviews. Energy Build. 2019, 203, 109423. [CrossRef]

27. Magalhães, S.M.; Leal, V.M. Characterization of thermal performance and nominal heating gap of the residential building stock using the EPBD-derived databases: The case of Portugal mainland. Energy Build. 2014, 70, 167-179. [CrossRef]

28. Palma, P.; Gouveia, J.P.; Simoes, S.G. Mapping the energy performance gap of dwelling stock at high-resolution scale: Implications for thermal comfort in Portuguese households. Energy Build. 2019, 190, 246-261. [CrossRef]

29. Silva, M.; Leal, V.; Oliveira, V.; Horta, I.M. A scenario-based approach for assessing the energy performance of urban development pathways. Sustain. Cities Soc. 2018, 40, 372-382. [CrossRef]

30. Monteiro, C.S.; Costa, C.; Pina, A.; Santos, M.Y.; Ferrão, P. An urban building database (UBD) supporting a smart city information system. Energy Build. 2018, 158, 244-260. [CrossRef]

31. Dias, L.; Simões, S.; Gouveia, J.; Seixas, J. City energy modelling-Optimising local low carbon transitions with household budget constraints. Energy Strategy Rev. 2019, 26, 100387. [CrossRef]

32. Fonseca, J.; Panão, M.J.O. Monte Carlo housing stock model to predict the energy performance indicators. Energy Build. 2017, 152, 503-515. [CrossRef]

33. Panão, M.J.O.; Brito, M.C. Modelling aggregate hourly electricity consumption based on bottom-up building stock. Energy Build. 2018, 170, 170-182. [CrossRef]

34. Figueiredo, R.; Nunes, P.; Panão, M.J.O.; Brito, M.C. Country residential building stock electricity demand in future climatePortuguese case study. Energy Build. 2020, 209, 109694. [CrossRef]

35. Penas, A. Energy Performance Certification: National and Regional Characterization of Residential Building Stock. Master's Thesis, Faculdade de Ciências da Universidade de Lisboa, Lisboa, Portugal, 2019.

36. Pinson, P.; Madsen, H.; Nielsen, H.A.; Papaefthymiou, G.; Klöckl, B. From probabilistic forecasts to statistical scenarios of short-term wind power production. Wind. Energy Int. J. Prog. Appl. Wind. Power Convers. Technol. 2009, 12, 51-62. [CrossRef]

37. Statistics Portugal. Statistical Data from Censos 2011; Statistics Portugal: Lisboa, Portugal. Available online: www.ine.pt (accessed on 7 July 2021).

38. Statistics Portugal. Anonymous Micro-Data Collected for Households Budget Survey (2015-2016) Accessed for Research; Statistics Portugal: Lisboa, Portugal, 2015; Unpublished.

39. Directorate General for Energy and Geology. Statistics. 2021. Available online: www.dgeg.pt (accessed on 6 July 2021).

40. Statistics Portugal and Directorate-General for Energy and Geology. Inquérito ao Consumo de Energia no Sector Doméstico; 2011. Available online: www.ine.pt (accessed on 6 July 2021). (In Portuguese)

41. Statistics Portugal. Preliminary Results of the Survey on Energy Consumption in Households (2020); Statistics Portugal: Lisboa, Portugal. Available online: www.ine.pt (accessed on 11 December 2021).

42. Portuguese Ministry of Economy and Employment. Decree-Law nr. 118/2013; 2013. Available online: https://data.dre.pt/eli/declei/118/2013/08/20/p/dre/pt/html (accessed on 11 July 2021). (In Portuguese)

43. Lisboa E-Nova. Intelligent Monitor for Efficient Decisions. Funded by ERSE under the National PPEC-Plan for Promoting Efficiency in Electricity Consumption, 2011-2012. Unpublished.

44. EN 15251; Indoor Environmental Input Parameters for Design and Assessment of Energy Performance of Buildings-Addressing Indoor Air Quality, Thermal Environment, Lighting and Acoustics. European Committee for Standardization: Brussels, Belgium, 2007.

45. EN ISO 13790; Energy Performance of Buildings, Calculation of Energy Use for Space Heating and Cooling. European Committee for Standardization and International Organization for Standardization: Brussels, Belgium, 2008. 
46. ISO 52016-1; Energy Performance of Buildings, Calculation of Energy Needs for Heating and Cooling, Internal Temperatures and Sensible and Latent Heat Loads-Part 1: Calculation Procedures. European Committee for Standardisation and International Organization for Standardization: Brussels, Belgium, 2017.

47. Nielsen, T.R. Simple tool to evaluate energy demand and indoor environment in the early stages of building design. Sol. Energy 2005, 78, 73-83. [CrossRef]

48. National Laboratory of Energy and Geology. Climate Data for Energy Performance Certification; National Laboratory of Energy and Geology: Lisboa, Portugal, 2006.

49. Portuguese Ministry of Construction, Transports and Communications. Decree-Law nr. 80/2006. Regulamento das Características do Comportamento Térmico dos Edifícios, RCCTE; 2006. Available online: https://data.dre.pt/eli/dec-lei/80/2006/04/04/p/dre/pt/ $\mathrm{html}$ (accessed on 11 July 2021). (In Portuguese) 